\title{
ANTI-TUBERCULAR ACTIVITY OF EXTRACT AND COUMPOUNDS OF NONI (MORINDA CITRIFOLIA LINN)
}

\author{
NOVIE E. MAULIKU ${ }^{1,2 *}$, HENDRO W. ${ }^{1}$, SUHARYO HADI SAPUTR0 ${ }^{1}$, TRI N. KRISTINA ${ }^{1}$ \\ ${ }^{1}$ Doctoral Program of Medical and Health Science, Faculty of Medicine, Diponegoro University, Semarang, Indonesia, 50241, ${ }^{2}$ Public Health \\ Study Program, School of Health Sciences Jenderal Achmad Yani, West Java Indonesia \\ Email: noviemauliku@gmail.com \\ Received: 09 May 2017 Revised and Accepted: 02 Nov 2017
}

\begin{abstract}
Objective: The study evaluated the anti-tubercular activity of crude extracts and active compounds which was isolated, purification and characterization from noni (Morinda citrifolia Linn) against Mycobacterium tuberculosis strains H37Rv.

Methods: The crude extract of the noni fruits was macerated using ethanol (96\%). Ethanol crude extracts were qualitatively screened to identify of the flavonoid, scopoletin, antraquinon and alkaloids using phytochemical fractionation by harborn method. The anti-tubercular activity of noni fruit and its combination were determined by the minimum inhibitory concentration (MIC) of the bacterial growth at various doses $10 \mathrm{mg} / \mathrm{ml}, 20 \mathrm{mg} / \mathrm{ml}$, $30 \mathrm{mg} / \mathrm{ml}$, and $40 \mathrm{mg} / \mathrm{ml}$ using agar well diffusion method. Statistical analysis was performed by analysis of variance.

Results: Crude extract and active compounds of noni fruit such as flavonoid, scopoletin, antraquinon and alkaloids significantly work as antitubercular against Mycobacterium tuberculosis strain $\mathrm{H} 37 \mathrm{Rv}$ at various doses (p value $=0,000)$. Crude extract $(59.00 \pm 60.513$ ), alkaloids

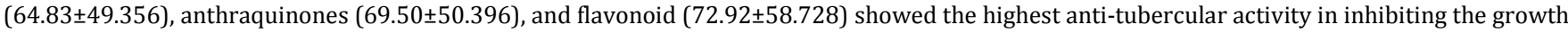
of Mycobacterium tuberculosis strain H37Rv compared to scopoletin (95.92 \pm 33.280$)$ and the negative control (189.25 \pm 33.280$)$. The minimum inhibitory concentration was found at a dose of $40 \mathrm{mg} / \mathrm{ml}$.
\end{abstract}

Conclusion: Crude extract of noni fruit was the most active anti-tubercular against Mycobacterium tuberculosis strains H37Rv. One can assume that noni fruit can be fruther researched to be used as adjuvant therapy for anti-tuberculosis drugs.

Keywords: Morinda citrifolia Linn., Anti-tubercular activity, Flavonoids, Scopoletin, Alkaloids, Anthraquinones

(C) 2017 The Authors. Published by Innovare Academic Sciences Pvt Ltd. This is an open access article under the CC BY license (http://creativecommons.org/licenses/by/4.0/) DOI: http://dx.doi.org/10.22159/ijpps.2017v9i12.19841

\section{INTRODUCTION}

Tuberculosis (TB) has been recognized as one of the major global health problems in the world. Since 1993 TB was declared as a global health emergency because more than half people in the world are infected by TB [1]. By 2015, world health organization (WHO) estimated that the incidence of new TB cases is around 10.4 million cases worldwide, whereas $60 \%$ of the cases are in developing countries. South-East Asia had been noticed to have the greatest burden of $\mathrm{TB}$, while Indonesia ranked as the second highest countries in the world with 1.02 million (395/100 000) new TB cases [2].

The high rates of TB incidence in both morbidity and mortality become a serious problem worldwide because the front line antituberculosis drugs have gradually become ineffective for TB therapy [3]. Multidrug-resistant tuberculosis (MDR-TB) is multifactorial and fuelled by improper treatment of patients, poor management of supply and quality of drugs, and airborne transmission of bacteria in public places. MDR-TB also caused by mutation of Mycobacterium tuberculosis that resistant to at least two component of front line anti-tuberculosis of the most potent drugs (rifampicin and isoniazid). Based on the results of the drug resistance survey, the estimated cases of MDR-TB in 2015 worldwide reached 580000 cases, consisting of $3.9 \%$ of new tuberculosis cases and $21 \%$ of TB cases with previous medical history. Another enormous problem recently discovered is a class of super bacteria known as extensively drug-resistant tuberculosis (XDR-TB), abbreviation for strains resistant to first and second line anti-tuberculosis drugs [4].

The treatments of infectious diseases facing serious problem worldwide, as microorganisms become resistant to multiple antimicrobial agents, which lead to increase TB cases incidence. Due to the emergence of new resistant bacterial strains to the majority of anti TB drugs, new therapeutic agents acting on novel targets, presenting early bactericidal activity as well as a fast intracellular sterilizing activity that could shorten current therapeutic regimens are urgently required. In spite of the growing efforts to discover effective anti-TB from medical approach, local plants traditionally used in Indonesia for the treatment of TB [5].

Noni is a small evergreen tree from the Indo-Pacific region and grows throughout the Indonesian archipelago. The plant is frequently uses in traditional medicine. All parts of the plant have been reported for therapeutic effects as antibacterial, antiviral, antifungal, antitumor, anthelmintic, analgesic, hypotensive, antiinflammatory, and enhance the immune effects [6-7]. Previous pharmaceutical study showed that, extract of noni fruits effectively inhibit gram-positive and gram-negative bacteria such as Staphylococcus aureus, Bacillus subtilis, Proteus morgaii, Pseudomonas, Escherichia coli [8-9] moreover, the plants also utilizes to control the groups of pathogen bacteria, such Salmonella and Shigella [10-12]. In addition research conducted by Saludes (2002), reported that noni has been found to kill Mycobacterium tuberculosis. A concentration of the ethanol extract and hexane fraction noni leaves killed $89 \%$ of the bacteria in a test tube, almost as effective as a leading anti-tuberculosis drug rifampicin, which has an inhabitation rate of $97 \%$ at the same concentration [13].

Other studies reported by Maria (2010) revealed that the ethanol extract of noni fruits showed that Noni possessed in vitro antimycobacterial effect against Mycobacterium tuberculosis bacteria at minimum inhibitory concentrations (MIC) $5 \mathrm{mg} / \mathrm{ml}$, and a range of $10 \mathrm{mg} / \mathrm{ml}$ against MDR-TB bacteria [14]. The anti-mycobacterial activities of noni lead by the presence of secondary metabolites and lectins, compounds that usually associate with the plants defense mechanisms.

Phytochemical investigations resulted in the isolation of approximately 200 compounds from different parts of noni [15]. 
Several classes of metabolites have been described in different parts, including acids, alcohols and phenols, anthraquinone, anthraquinone glycosides, carotenoids, esters, flavonoids, iridoids, ketones, lactones, lignans, nucleosides, triterpenoids, sterols and several minor compounds. The antibacterial compounds in the noni fruit ranged from $5.94 \mathrm{~g}$ to $36.52 \mathrm{~g} / 100 \mathrm{~g}$ of dry material [16-17]. A number of major components have been identified in the noni plant as an antibacterial such as scopoletin, terpenoids, alkaloids, anthraquinones, and flavonoids [14, 17].

The mechanisms of antimicrobial action of plant secondary metabolites are not fully understood, but several studies have been conducted that secondary metabolites of noni is a phenolic compound that can damage cell membranes, inactivate enzymes and denature proteins in bacteria, therefore the bacterial cell wall will be damaged, furthermore it can acts as an antibacterial compound in inhibiting or even kill bacteria [20].

The study aimed to prove the anti-tubercular activity of extract and its compounds of noni such flavonoid, antraquinon, scopoletin, and alkaloids at measured doses of $10 \mathrm{mg} / \mathrm{ml}, 20 \mathrm{mg} / \mathrm{ml}, 30 \mathrm{mg} / \mathrm{ml}$, and $40 \mathrm{mg} / \mathrm{ml}$ against Mycobacterium tuberculosis strain H37Rv. Furthermore, this study aimed to obtain the most potential compound and effective dose in inhibiting the growth of Mycobacterium tuberculosis bacteria, as well as to identify the difference growth of bacterial colonies either from variation type of compound or dose.

\section{MATERIALS AND METHODS}

\section{Chemical and reagents}

Chameical and reagent utilized in this study were, etanol, etil asetat, n heksana, aquabidestilata, iron (II) klorida, natrium hidroksida $1 \%$, (CV. Griya Sarana Meditama, Bandung, Indonesia), Dragendorff, siliksa gel (Merck no. 60GF.254), PLAT KLT6F 254, sodium chloride (NACL) 10\%, dimethyl sulfoxide (DMSO), Ammonium sulphate, L. glumatic acid, sodium citrate (PT. Biogen Scientific Indonesia), Scopoletin, quercetin, alkaloid and alizarin were obtained from Sigma-Aldrich Chemicals (PT. Eko Karsa Utama), Lowenstein Jensen (Merck no. 105400), and glyserol (Merck cat. no. 104094).

\section{Plant material}

The plant material of the present study is fresh mature of noni fruit that was collected during the rainy season in Cibeber, South Cimahi (2.8 Km from Cimahi city), West Java province, Indonesia. The plant voucher specimens of noni fruit (EN-no. 241571) were identified and authenticated at the Biomedical Sciences Laboratory of the School of Health Sciences Jenderal Achmad Yani Cimahi. The fresh mature noni fruits was cleaned and sliced into small pieces, shadedried at $50{ }^{\circ} \mathrm{C}$ and ground to powder.

\section{Extraction and isolation}

The powdered noni fruit material (500 gr) was macerated with $500 \mathrm{ml}$ ethanol $(96 \%)$ in the increasing order of polarity from non-polar to high polar at $50{ }^{\circ} \mathrm{C}$ for $2 \mathrm{~h}$. The extract was filtered through Whatman No.1 filter paper, evaporated to dryness on a water bath until the solvent evaporated completely and yield of the crude extract. The crude extracts were used for preliminary screening of phytochemicals such flavonoid (Shinoda's test, lead acetate test), scopoletin (HPLC analysis, silica gel), antraquinon (HPLC analysis, LC-MS), and alkaloids (Hagers, Mayers, Dragendorff test) using the Harbone method. The presence of flavonoids compounds was indicated by the appearance of color pink to red.

Antraquinon compounds were indicated by the formation of yellow, while alkaloid was shown by the appearance of a clear yellow color, and the presence of scopoletin was indicated by blue [21].

\section{Bacterial strains}

The Mycobacterium tuberculosis strain H37Rv used in this study was derived from patients with active TB which drug-susceptible sensitive to the first-line anti-tubercular drugs at the Health Laboratory of West Java Province Indonesia.

\section{Experiment protocol}

The experiment were divided into 6 groups, i.e.: control group; group I: crude extracts noni; group II: flavonoid; group III: scopoletin; group IV: antraquinon; and group V: alkaloid. Each groups were divided into four groups concentration of $10 \mathrm{mg} / \mathrm{ml}, 20$ $\mathrm{mg} / \mathrm{ml}, 30 \mathrm{mg} / \mathrm{ml}$ and $40 \mathrm{mg} / \mathrm{ml}$. Anti-tuberculosis activity of different solvent extracts of noni were tested against Mycobacterium tuberculosis strain H37Rv obtained from health laboratory West Java Province Indonesia and the strains were maintained on nutrient broth and incubated for $7 \mathrm{~h}$ at $37{ }^{\circ} \mathrm{C}$ to standardize the culture to $10^{8} \mathrm{CFU} / \mathrm{ml} .10 \mathrm{mg} / \mathrm{ml}, 20 \mathrm{mg} / \mathrm{ml}, 30 \mathrm{mg} / \mathrm{ml}$ and $40 \mathrm{mg} / \mathrm{ml}$ crude extract and the compounds from noni was dissolved in $1 \mathrm{ml}$ of $20 \%$ DMSO (dimethyl sulfoxide). The respective solvent was added aseptically to the sterile empty lowenstein-jensen (LJ) broth agar (glycerol, duck egg, L-asparagine, malachite green 2\%) at temperature $121{ }^{\circ} \mathrm{C}$ and $\mathrm{pH}$ 8-7. The LJ agar poured into a bottle of Mc Carteney sterile as much as 6-8 ml. After drying inoculation the $100 \mathrm{ml}$ dilution $10^{3}$ of bacilli Mycobacterium tuberculosis strain H37Rv on the whole surface of the medium LJ. Incubation the medium with the horizontal position with the slope of $300^{\circ}$ in the temperature $37{ }^{\circ} \mathrm{C}$. All assays were run in duplicate, and streptomycin $(0.5 \mathrm{mg} / \mathrm{ml})$, isoniazid $(0.06 \mathrm{mg} / \mathrm{ml})$ and rifampicin $(0.1 \mathrm{mg} / \mathrm{ml})$ were utilized as positive controls.

\section{Anti-tuberculosis activity}

The anti-tuberculosis activity of each ekstrak and compound was measure based on minimum inhibitor concentration (MIB) values expressed as the lowest concentration inhibition growth of colonies Mycobacterium tuberculosis, while the determination of minimum bactericidal concentration (MBC) was indicated by clear zones around the medium [22-23].

\section{Statistical analysis}

All data were analysis using univariate analysis of variance, and the differences means \pm standard deviation between each group were evaluated by least significant difference (LSD) and Duncan's statistical analysis in this study using confidence interval 95\% ( $\mathrm{p} \leq 0.05)$.

\section{RESULTS}

Crude extract and active compounds of noni fruit such as flavonoid, scopoletin, antraquinon, and alkaloid showed the activity of antituberculosis. The anti-tuberculosis of crude extract and active compound of noni fruit have different mean number of growth colonies Mycobacterium tuberculosis at various doses $10 \mathrm{mg} / \mathrm{ml}, 20$ $\mathrm{mg} / \mathrm{ml}, 30 \mathrm{mg} / \mathrm{ml}$, and $40 \mathrm{mg} / \mathrm{ml}$ (fig. 1)

The number of colonies Mycobacterium tuberculosis strain H37Rv bacteria at a dose of $10 \mathrm{mg} / \mathrm{ml}$ showed that alkaloids exhibit smaller mean compared to other group $(109.67 \pm 10.21)$. At a dose of 20 $\mathrm{mg} / \mathrm{ml}$, the growth of bacterial colonies of crude extract, alkaloid, and flavonoid were a smaller than anthraquinon and scopoletin, however, at the dose of $30 \mathrm{mg} / \mathrm{ml}$ demonstrate the least ability to inhibit bacterial growth $(6.67 \pm 11.55)$ compared to other compounds. Furthermore, at a dose of $40 \mathrm{mg} / \mathrm{ml}$, did not showed any bacterial colonies of Mycobacterium tuberculosis strain H37Rv on the media, one can be assumed that the crude extract, flavonoid, antraquinon, and alkaloid had bactericidal effect against the Mycobacterium tuberculosis bacteria (table 1).

Anti-tubercular activity of the extract and compounds of noni showed a significant inhibition for the growth of Mycobacterium tuberculosis strain H37Rv compared to the negative control $(\mathrm{p}<0.01)$. All of the compounds of noni as well as positive control, anti-tubercular activity against Mycobacterium tuberculosis bacteria, and the MIC determinations showed that the crude extract of noni fruit was the most active amongst the pure isolated compounds. The further investigation found that crude extract, alkaloids, anthraquinone, and flavonoids of noni fruits have higher anti-tubercular activity compare to scopoletin and negative control (table 2).

The difference mean of the colonies of bacterial growth Mycobacterium tuberculosis strain H37Rv with various doses in the 


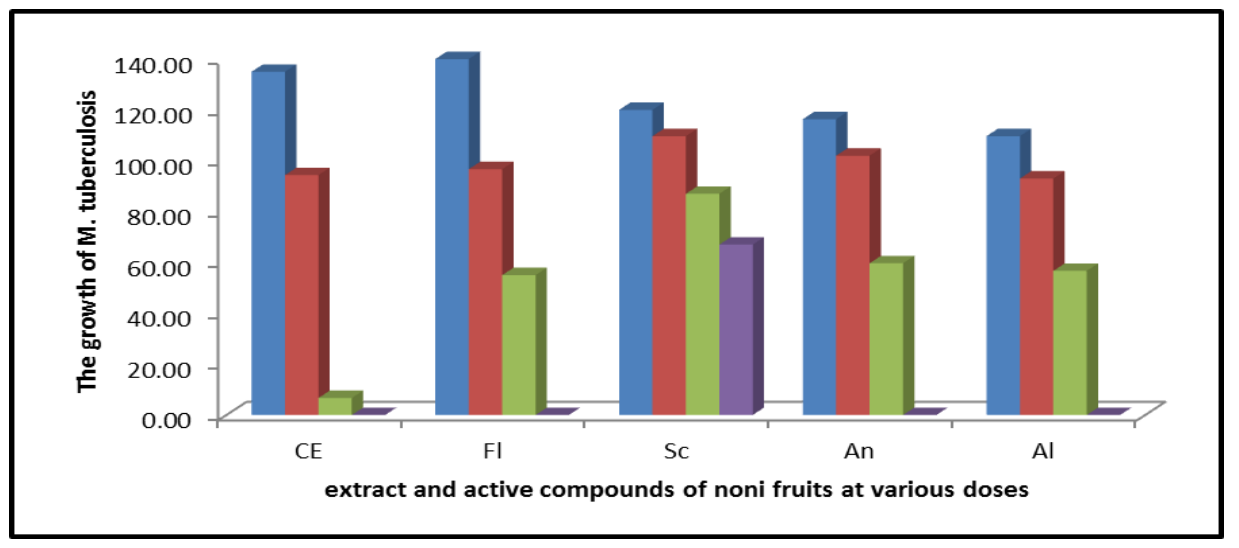

Fig. 1: The growth of $M$. tuberculosis in different $\mathrm{CE}=$ crude extract, $\mathrm{Fl}=\mathrm{Flavonoid}, \mathrm{Sc}=\mathrm{Scopoletin}, \mathrm{An}=$ antraquinon, $\mathrm{Al}=$ alkaloid at various doses $10 \mathrm{mg} / \mathrm{ml}, 20 \mathrm{mg} / \mathrm{ml}, 30 \mathrm{mg} / \mathrm{ml}$, and $40 \mathrm{mg} / \mathrm{ml}$ with $\mathrm{n}=86$. Values represent the mean $\pm S D$ of the two determinants. The values followed by different superscript differ significantly at $p<0.05$

Table 1: Antimicrobial activity of crude extracts and compounds of M. citrifolia Linn (noni) fruit at various doses

\begin{tabular}{lllll}
\hline Sample & Doses $\mathbf{( m g} / \mathbf{m l})$ & & & \\
\cline { 2 - 5 } & $\mathbf{1 0} \mathbf{~ m g} / \mathbf{m l}$ & $\mathbf{2 0} \mathbf{~ m g} / \mathbf{m l}$ & $\mathbf{3 0} \mathbf{~ m} / \mathbf{m l}$ & $\mathbf{m g} / \mathbf{m l}$ \\
\hline CE & $135.0000 \pm 10.00$ & $94.33 \pm 6.35$ & $6.67 \pm 11.55$ & $0.00 \pm 0.00$ \\
Fl & $140.00 \pm 18.03$ & $96.67 \pm 9.07$ & $55.00 \pm 50.09$ & $0.00 \pm 49.43$ \\
Sc & $120.00 \pm 8.72$ & $109.67 \pm 10.69$ & $87.00 . \pm 30.51$ & $67.00 \pm 0.00$ \\
An & $116.33 \pm 8.50$ & $102.00 \pm 17.00$ & $59.67 \pm 36.64$ & $0.00 \pm 0.00$ \\
Al & $109.67 \pm 10.21$ & $93.0 \pm 13.23$ & $56.67 \pm 50.08$ & $0.00 \pm 0.00$ \\
\hline
\end{tabular}

$\mathrm{CE}=$ crude extract, $\mathrm{Fl}=$ Flavonoid, $\mathrm{Sc}=\mathrm{Scopoletin}, \mathrm{An}=$ antraquinon, $\mathrm{Al}=$ alkaloid Inhibitory zones in $\mathrm{mm}$, represented as mean $\pm \mathrm{SD}$ values $(\mathrm{n}=86), 0.00$ $=$ no zone. The values followed by different superscript differ significantly at $\mathrm{p}<0.05$

Table 2: The difference mean anti-tuberculosis activity extract and compounds of noni fruits against Mycobacterium tuberculosis bacteria (H37Rv)

\begin{tabular}{|c|c|c|c|c|}
\hline Sample & & Mean & SD & $p$ value \\
\hline \multirow[t]{6}{*}{ CE $(59.00 \pm 60.513)$} & Control- & 189.25 & \pm 25.191 & $0.000^{*}$ \\
\hline & Control+ & 0.00 & \pm 00.000 & 0.705 \\
\hline & $F l$ & 72.92 & \pm 58.728 & 0.219 \\
\hline & Sc & 95.92 & \pm 33.280 & $0.002^{*}$ \\
\hline & $A n$ & 69.50 & \pm 50.396 & 0.353 \\
\hline & $A l$ & 64.83 & \pm 49.356 & 0.605 \\
\hline
\end{tabular}

$\mathrm{CE}=$ crude extract, $\mathrm{Fl}=$ Flavonoid, $\mathrm{Sc}=\mathrm{Scopoletin}, \mathrm{An}=$ antraquinon, $\mathrm{Al}=$ alkaloid Inhibitory zones in $\mathrm{mm}$, represented as mean $\pm \mathrm{SD}$ values $(\mathrm{n}=86)$. The values followed by different superscript differ significantly at $\mathrm{p}<0.05$. The mark indicate significant differences compared with the crude extract (LSD post hoc test; ${ }^{*}=\mathrm{p}<0.05 ;{ }^{* *}=\mathrm{p}<0.01$ )

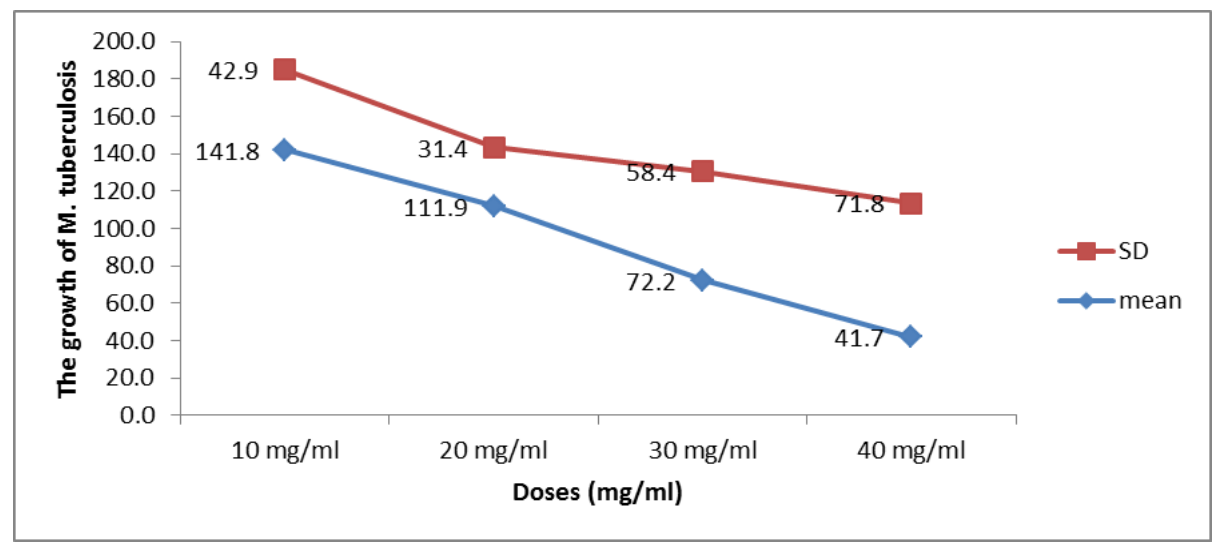

Fig. 2: The different growth of $M$. tuberculosis in various doses $10 \mathrm{mg} / \mathrm{ml}, 20 \mathrm{mg} / \mathrm{ml}, 30 \mathrm{mg} / \mathrm{ml}$, and $40 \mathrm{mg} / \mathrm{ml}$ with n=86. Values represent the mean $\pm S D$ of the two determinants. The values followed by different superscript differ significantly at $p<0.05$ 


\section{DISCUSSION}

The antibacterial activity of ethanol extract and compounds from noni fruits, as well as some other compounds in noni root and leaves, are all proved as antibacterial agents. The results of the present study showed the crude extract, flavonoid, scopoletin, antraquinon, and alkaloid have a significant difference of the growth of Mycobacterium tuberculosis strain H37Rv. The antibacterial activity of noni against certain infectious bacterial strains was reported [8, 12]. Malinggas et al. (2015) reported that noni fruit extract can inhibit zone diameter Streptococcus mutant growth in $330.66 \mathrm{~mm}^{2}$ [36]. Another study of affectivity noni against E. coli, Salmonella typhii, and Bacillus cereus, C. albicans, and S. aureus reported by Usha (2010) [11]. Anti-tubercular effects of Saludes research, reported that leaves form noni has been found killed 89 percent of the bacteria M. tuberculosis [13].

The activity of anti-tubercular might be influenced by the presence of secondary metabolites as phenolic compounds. Phenolic compounds contained in the noni fruit ranged from 5.94 to 36.52 $\mathrm{g} / 100 \mathrm{~g}$ of dry material [24]. Solvent organic extracts contain a mixture of secondary metabolites including alkaloids, flavonoids, terpenoids, and other phenolic compounds; these molecules are associated with the defense mechanisms of plants by their repellent or attractive properties, protection against biotic and abiotic stresses, and maintenance of structural integrity of plants $[15,28]$, and the class of natural compounds possessing a wide range of pharmacological activities [29,30].

The mechanism of phenol compounds in their role as antibacterial is to damage cell membranes, activate enzymes and denaturate proteins so that cell walls are damaged by decreased permeability. It further disrupts the transport of important organic ions into the cells resulting in inhibition of growth even to cell lysis [28]. The mechanisms antibacterial activity of compounds of plants extract is different each secondary metabolites. Flavonoids may act through inhibiting cytoplasmic membrane function as well as by inhibition of DNA gyrase and $\beta$-hydroxyacyl-acyl carrier protein dehydratase activities [19, 31]. Alkaloids was reported by Kishore et al. (2009), that alkaloids have been found more effective anti-tubercular against M. tuberculosis [30]. The mechanism of alkaloid compounds is by disrupting the peptidoglycan component of the bacterial cell so that the cell wall layer is not formed intact and affect the amino acids of cell wall and bacterial DNA [6, 33]. The antibacterial mechanism of anthraquinone and scopoletin is no different from the mechanism of ethanol extract, flavonoids and alkaloids that activate the enzyme and denatures the bacterial protein, so that the cell wall is damaged [17, 34-35].

Although a number of publications have focused on the isolation and identification of bio-active compounds, it is important to keep in mind that a single compound may not be responsible for the observed activity but rather a combination of compounds interacting in an additive or synergistic manner.

\section{CONCLUSION}

The present study brought out the fact that crude extract and its compounds from Morinda citrifolia Lin (noni) fruit such as flavonoid, scopoletin, antraquinon, and alkaloid have antituberculosis activity against M. tuberculosis (H37RV). The crude extracts of noni fruits was the most active compound compared the other group against $M$. tuberculosis (H37RV). The minimum inhibitory dose of noni fruit against M. tuberculosis (H37Rv) bacteria is $40 \mathrm{mg} / \mathrm{ml}$. Based on the results obtained, noni fruits can be a potential source of drugs as an adjuvant therapy for antituberculosis drugs. However, further studies required to carry out in in vivo, ex vivo and clinical trial investigations of $M$. citrifolia Linn for alternative treatment of tuberculosis problems.

\section{ACKNOWLEDGMENT}

This research was partially funded by desentralisasi 2015 grants from the Indonesian Ministry of Research and Technology, Scholarships from BPP-DN, Indonesia Ministry of Research and Technology. We thanks to Prof. dr. Edi Dharmana, Sp. Par(K), M. sc, Ph. D; Prof dr. HardhonoSusanto, PAK(K); Dr. Muchlis AUS., SpPD-
KPTI; Dr. dr Sri Andarini I., M. Kes, Dr. Dyan K. Nugrahaeni, SKM., MKM and Susiana, SKM., MN to their contribute for this research.

\section{AUTHOR CONTRIBUTION}

All persons who meet authorship criteria are listed as authors and all authors certify that they have participated sufficiently in the work to take public responsibility for the content, including participation in the concept, design, analysis, writing, or revision of the manuscript. Furthermore, each authors certifies that this material or similar material has not been and will not be submitted to or published in any other publication before its appearance in International Journal of Pharmacy and Pharmaceutical Sciences

\section{CONFLICT OF INTERESTS}

\section{Declared none}

\section{REFERENCES}

1. World Health Organization. Global tuberculosis report. Switzerland; 2016.

2. World Health Organization. Tuberculosis profile. Switzerland; 2016.

3. World Health Organization. Treatment guidelines for drugresistant tuberculosis. Switzerland; 2016.

4. World Health Organization. Companion handbook: to the WHO guidelines for the programmatic management of drug-resistant tuberculosis. Switzerland; 2016.

5. Motshakeri M, Ghazali HM. Nutritional, phytochemical and commercial quality of noni fruit: A multi-beneficial gift from nature. Trends Food Sci Technol 2015;45:118-29.

6. Haque M, Rao USM. Modulatory effect of noni fruit on the activities of key enzymes of glucose synthesis and utilization pathways of diabetic induced rats. J Pharm Res 2013;7:53-61.

7. Pandy V, Narasingam M, Kunasegaran T, Murugan DD, Mohamed Z. Effect of noni (Morinda citrifolia Linn.) fruit and its bioactive principles scopoletin and rutin on rat vas deferens contractility: an ex vivo study. Sci World J 2014:1-11. Doi:10.1155/2014/909586

8. Singh DR. Morinda citrifolia L. (Noni): a review of the scientific validation for its nutritional and therapeutic properties. J Diabetes Endocrinal 2012;3;6:77-91.

9. Gupta RK, Patel AK. Do the health claims made for Morinda citrifolia Linn (Noni) harmonize with current scientific knowledge and evaluation of its biological effects. Asian Pac J Cancer Prev 2014;8:4495-9.

10. Antara NS, Prabanca VG, Ekawati IGA. Antimikrobia activity of extracts noni (Morinda citrifolia L.) fruit against pathogen bacteria. Media Ilmiah Teknol Pangan 2014;1:1-9.

11. Usha R, Sashidharan S, Palaniswamy M. Antimicrobial activity of a rarely known species, Morinda citrifolia $L$. Ethnobotanical Leaflets 2010;14:306-11.

12. West BJ, Palmer SK, Deng S, Palu AK. Antimicrobial activity of an Iridoid rich extract from Morinda citrifolia fruit. Curr Res J Biol Sci 2012;4:52-4.

13. Saludes JP, Garson MJ, Franzblau SG, Aguinaldo AM. Antitubercular constituents from the hexane fraction of Morinda citrifolia Linn (Rubiaceae). Phytoher Res 2002;16:683-6.

14. Tuntun M, Andriansjah, Mun'im A. Susceptibility testing of MDR-TB and XDR-TB to noni fruit ethanol extract (Morinda citrofilia L), red ginger (Zingiber officunale R) aA/Mnd combination of both. J Bahan Alam Indonesia 2011;7:355-8.

15. Markandeyan D, Santhalingam K, Kannaiyan S, Suresh S, Paul B. Virtual screening of phytochemicals of Morinda citrifolia as anti-alzheimer agents using molegro virtual docker on p38 $\alpha$ mitogen-activated protein kinase enzyme. Asian J Pharm Clin Res 2015;8:141-5.

16. Sathishkumar G, Gobinath C, Karpagam K, Hemamalini V, Premkumar K, Sivaramakrishnan S. Phyto-synthesis of silver nanoscale particles using Morinda citrifolia L. and its inhibitory activity against human pathogens. Colloids Surf B 2012;95:23540 .

17. Deng S, West BJ, Jensen CJ. A quantitative comparison of phytochemical components in global noni fruits and their commercial products. Food Chem 2010;122:267-70. 
18. Pawlus AD, Kinghorn AD. Review of the ethnobotany, chemistry, biological activity and safety of the botanical dietary supplement Morinda citrifolia L. (noni). J Pharm Pharmacol 2007;59 Suppl 1:1587-609.

19. Anwar K, Triyasmono L. The compound of total phenolic, total flavonoid, and the antioxidant activity of ethaol extract of noni fruits (Morinda citrifolia L.). J Pharmasci 2016;3:83-92.

20. Martins D, Nunez CV. Secondary metabolites from Rubiaceae species. Molecules 2015;20:13422-95.

21. Ramamoorthy SP, Manickam D, Subramaniam S, Subramaniam S. Standardization and phytochemical screening of traditional formulation. Int J Curr Pharm Res 2017;1:70-4.

22. Brooks GF, Carroll KC. Mycobacteria. In: Medical Microbiology. $24^{\text {th }}$ ed. Jawetz, Melnick, Adelberg's. Eds. USA: The McGraw-Hill Companies, Inc; 2007. p. 320-31.

23. Ríos JL, Recio MC. Medicinal plants and antimicrobial activity. J Ethnol Pharmacol 2005;100:80-4.

24. Rogoza LN, Salakhutdinov NF, Tolstikov GA. Anti-tuberculosis activity of natural products: recent developments. Chemistry for sustainable developments 2011;661:103-20.

25. Nugrahaeni DK, Hadisaputro S, Suwondo A, Dharmana A. The effect of alpha-mangostin in balancing the ratio of cytokines pro-and anti-inflammation gamma (IFN- $\gamma / \mathrm{IL}-10)$ and severity of the disease in mice infected with Mycobacterium tuberculosis multidrug-resistant. Asian J Pharm Clin Res 2016;9 Suppl 2:273-7.

26. Malinggas F, Pangamanan DHC, Mariati NW. The inhibition power from noni fruit extract (Morinda citrifolia L) to Streptococcus mutant's growth. Pharmacon J Ilm Farm Unsrat $2015 ; 4: 2302-493$
27. Dewi N. The usefulness and mechanism of noni fruit as therapy of the diseases. Yogyakarta Pustaka Baru Press; 2012.

28. Potterat O, Hamburger M. Morinda citrifolia (Noni) fruitphytochemistry, pharmacology, safety. Planta Med 2007 73:191-9.

29. George SA, Bhadran S, Sudhakar M, Harini. Comprehensive in vitro evaluation of pharmacological activities of selected plant extracts and gas chromatograph y-mass spectrometry profiling of flacourtia jangomas flower extract. Asian J Pharm Clin Res 2017; $10: 23744$

30. Arya V. A review on anti-tubercular plants. Int J Pharm Tech Res 2011;3:872-80.

31. Hossain MA, Al Kalbani MS, Al Farsi SAJ, Weli AM, Al-Riyami Q. Comparative study of total phenolics, flavonoids contents and evaluation of antioxidant and antimicrobial activities of different polarities fruits crude extracts of Datura metel $L$. Asian Pacific J Trop Dis 2014;4:383-8.

32. Kishore N, Mishra BB, Tripathi V, Tiwari VK. Alkaloids as potential anti-tubercular agents. Fitoterapia 2009;80:140-63.

33. Fouotsa H, Mbaveng AT, Mbazoa CD, Nkengfack AE, Farzana $S$, Iqbal CM, et al. Antibacterial constituents of three Cameroonian medicinal plants: Garcinia nobilis, Oricia suaveolens and Balsamocitrus camerunensis. BMC Complement Altern Med 2013;13:10-1

34. Duraipandiyan V, Al-Dhabi NA, Ignacimuthu S. New antimicrobial anthraquinone 6,61-bis (1,5,7-trihydroxy-3hydroxymethylanthraquinone) isolated from Streptomyces $s p$. isolate ERI-26. Saudi J Biol Sci 2016;23:731-5.

35. Bao L, Qin L, Liu L, Wu Y, Han T, Xue L, et al. Anthraquinone compounds from Morinda officinalis inhibits osteoclastic bone resorption in vitro. Chem Biol Interact 2011;194:97-105. 